\title{
A COMPARATIVE STUDY OF REAL FULL SCALE GROUND RECTANGULAR WATER TANK IN DUHOK CITY
}

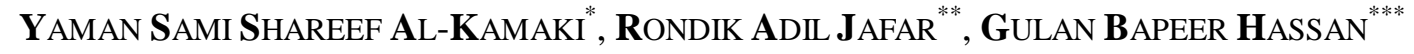 \\ and ALAA ALSAAD ${ }^{* * * *}$ \\ "Dept. of Civil Engineering, College of Engineering, University of Duhok, Kurdistan Region-Iraq \\ ** Dept. of Water Resources Engineering, College of Engineering, University of Duhok, Kurdistan \\ Region-Iraq \\ ${ }^{* * *}$ Dept. of Civil Engineering, College of Engineering, University of Duhok, Kurdistan Region-Iraq \\ ${ }^{* * * *} \mathrm{Al}$ Hashemi Consultant, United Arab Emirates
}

(Accepted for Publication: December 8, 2020)

\begin{abstract}
It is well known that facilities like storage reservoirs and tanks have a great priority as it serves mainly for portable drinking water for a huge population. In general, water tanks are designed based on their shapes and ground positions. In this comparative study an attempt is made to consider a rectangular reinforced concrete (RC) ground water tank of a real full scale as a case study in Duhok city. Two identical surface water tanks of a 9000 cubic meter capacity and having $50 \mathrm{~mm}$ joint in between have been undertaken in this study. The tank were analyzed and design manually based on working stress method to ensure that it is crack-free to avoid any leakage. The outcomes were then evaluated using ETABS, SAP2000 and SAFE software by performing three dimensional (3D) analyses. The mat foundation and top slab of the tank were analyzed using SAFE software. The study involves calculations of bending moments, shear forces, and reinforcement. The tank walls are subjected to dead load and hydrostatic load due to water. A parametric study has been undertaken also by considering water level and soil bearing capacity as variables in this investigation. A good agreement has been obtained in this comparison. It may be deduced that a design software can be used accordingly with a reasonable degree of accuracy than manual calculations. This can maintain a reasonable cost and avoid human errors in any structure which is a critical local and global issue nowadays.
\end{abstract}

KEYWORDS: Analysis and Design; Comparative study; Hydrostatic load; Parametric study; Soil subgrade pressure; Water tanks.

\section{INTRODUCTION}

A storage tank is an important structure used around the world which can be made as steel or RC structures (Yukio, 2010). Such water tank can be used for different type of liquids such as drinking water, irrigation, petrol, chemicals, firefight etc. In general, there are three types of water tanks depending on their real position, such as underground on ground (resting on ground) and overhead (elevated) water tanks (Ghandhi \& Rajan, 2014; Titiksh, 2019). Commonly according to their shapes, water tanks could be classified in various forms such as, circular, rectangular and Intze (Bekele, 2019).

yaman.alkamaki@uod.ac, rondik.adil@uod.ac, gulan@uod.ac, a.alsaad2012@gmail.com ${ }^{2}$ Corresponding author: Water Resources Engineering Department, College of Engineering, University of Duhok, Kurdistan Region, Iraq 
The design of RC liquid retaining structures comprises numerous tedious calculations and/or many design charts (Threlfall, 1978). Such calculations may take a long time to finalize any design. Therefore, a computer program RCTANK was developed by Chau and Lee (1991) in the past and verified for designing liquid retaining tanks. The later study demonstrated that the RCTANK being capable to deal with the analysis and design of RC water tanks and it had been strongly believed that this computer application will be promising. However, RCTANK was limited to analysis of tanks with a maximum height of $6 \mathrm{~m}$ (Elansary, 2016). For underground tanks, the analysis and design is established based on uncracked section theory, in order to overcome any leakage of stored liquids. The vertical walls of such tanks are exposed to soil and hydro-static pressures in which to be designed using working stress or limit state method for different edge conditions. Such edge conditions are: (a) hinged at top and bottom (b) hinged at top and fixed at bottom and (c) fixed at bottom and free at top (Bureau of Indian Standards, 1967).

Kukreti and Siddiqi (1997) predicted numerically the flexural behavior of a cylindrical storage tank resting on an isotropic elastic soil medium using differential quadrature solution method. The outcomes compared well with the Finite Element Analysis (FEA) results of a comparable problem, but with much less computational efforts. Magnucki and Stasiewicz (2003) considered underground and on ground cylindrical tanks. The ground tanks were loaded with internal hydrostatic pressure and small negative pressure while the underground tanks were positioned in water containing soil and loaded with external hydrostatic pressure. Depending on solving the equation of stability of cylindrical shell, critical conditions of both structures were calculated. Dimensionless tank length and dimensionless critical thickness have been recognized as functions to be used to determine the critical sizes of the tanks. Sharma, Singh, and Sharma (2008) investigated the fact that tank walls are normally cast monolithic with cover slab creating a condition in which both top and bottom ends are fixed. For this purpose, the study aimed to develop design tables for such condition using exact analysis and STAAD Pro computer program. It has been stated that STAAD Pro can be used valuably with reasonable degree of accuracy as the software is computationally economical. Hilo and Badaruzzaman (2011) made a comparison between the ACI and Euro codes to design a rectangular water tank. Twelve different cases were modeled with the aid of STAAD Pro software. The authors found that the Euro code was more optimum in design than ACI code by $6 \%$, thus it was suggested that Euro code to be used in the design of concrete water tanks. Qureshi, Amin, Janjua, and Tahir (2013) investigated 2D and 3D FEA of soil-structure interaction of Under Ground Water Tanks (UGWT) using Geotechnical and Tunnel Analysis System (GTS) software. The analysis was capable for calculating stresses and forces of both soil and structures. It was recommended that the UGWT should be designed using 3D FEM elements. Iqbal, Chowdhury, Sarker, and Anwar (2015) studied Finite Element Method (FEM) of UGWT using SAP2000 software considering length-height ratio, width-height ratio, wall thickness and soil density as main parameters. Two triangular loads were considered, outside soil load and inside water load in the tank. It has been found that maximum moments and shear increase with thickness of wall and as soil increases. Ajagbe, Ilugbo, Labiran, and Ganiyu (2015) considered the analysis and design of a fully submerged underground $\mathrm{RC}$ water tank using the principle of beam on elastic foundations. Microsoft excel spreadsheet design and analysis program 
MESDA Pro was used to determine moments, geometrical features and soil conditions for both full and empty conditions of the tank. It was concluded in all the examined cases that the moments obtained were higher when the tank was considered empty. Gulin, Uzelac, Dolejš, and Boko (2017) used Euro code to show the design of an aboveground vertical steel water-storage tank with a variable thickness wall and stiffening ring on top. The authors have compared the results obtained using the norms with those from a FEM analysis using SCIA Engineer (2008) software. The authors suggested to use a software tool that can analyze 3D structural solid elements, which can be used to accurately define fluid properties and fluid-solid interactions. Nallanathel, Ramesh, and Jagadeesh (2018) presented discussions about the analysis and design of underground and overhead water tanks of different shapes using STAAD Pro software. The consequences indicated that the results obtained were very accurate than conventional results.

For elevated water tanks, earthquake can induce large horizontal and overturning forces. This is expected due to their basic pattern involving large mass concentrated at top with relatively slender supporting system, so such tanks are vulnerable to damage in earthquakes (Patel \& Shah, 2010). Many investigators studied the effected of earthquake on elevated water tanks. Patel and Shah (2010) addressed the formulation of fundamental factors for seismic response modification factor $(\mathrm{R})$ on $\mathrm{RC}$ framed staging of elevated water tank. The estimation of $\mathrm{R}$ had been done by using static nonlinear pushover analysis. It has been noted that Pushover analysis is an advanced tool to carry out static nonlinear analysis of framed structures. Gate'a and Atalla (2015) studied free vibration analysis for an empty elevated concrete cylindrical liquid storage tank supported on a frame consisted of four stories. The FEM using
ANSYS 11 was facilitated for modeling. The dynamic response with the maximum stresses and displacements had been determined and discussed. The authors stated that the natural frequency decreases as frame height increases, when frame height is doubled the natural frequency increment is found to be equal $68 \%$. Naik and Bhandiwad (2016) investigated the seismic behavior of an elevated rectangular water tank of different seismic zones as per Bureau of Indian Standards Part 21893 BIS (2002) and wind speed for different soil conditions. The tank had been modelled using ETABS software and had optimized by $\mathrm{N}$ Pandian method to give the optimum and economical design of water tank. The authors advised that elevated rectangular water tanks must be designed as two mass spring model as the effect of hydrodynamic pressure is very significant and must be accounted. Yazdanian, Razavi, and Mashal (2016) examined the seismic behaviour of rectangular concrete tanks. These tanks were analyzed under four types of analysis: static, modal, response-spectrum and time-history. They concluded that displacement, base shear and wave height obtained from time history analysis are more than those of response spectrum analysis. Zhao, $\mathrm{Hu}$, Chen, Lim, and Wang (2018) studied nonlinear sloshing in rectangular tanks under forced excitation. The author stated that sloshing under horizontal and rotational excitations share similar properties. Resonant sloshing will be excited when vertical excitation lies in the instability zone. It was distinguished through the review of literature that a few researches concentrated on earthquake of ground water tank. AbdulMuttalib I. Said and Ammar A. AbdulMajeed (2011) studied earthquake excitations for rectangular storage tanks. A linear 3D FEA has been used to predict the natural frequencies. Three Analysis parameters were considered, level of water in the tank, the type of soil, height to length of the tank

yaman.alkamaki@uod.ac, rondik.adil@uod.ac, gulan@uod.ac, a.alsaad2012@gmail.com ${ }^{2}$ Corresponding author: Water Resources Engineering Department, College of Engineering, University of Duhok, Kurdistan Region, Iraq 
and also the wall thickness. The results for top displacement and axial force components for a full tank above ground case have given values greater than those in half- full and empty tank cases. For the current comparative study, the seismic behaviour was not considered due to that fact that the presence of infill walls in perimeter frames and the existing columns increases considerably the stiffness of the two adjacent tanks and their global resistance to lateral loads.

In general, according to the minimum cost of a tank, the shape can be chosen. Tam, Tam, and Zeng (2010) discussed the cost effectiveness of rainwater tanks. The authors found that using rainwater is an economical opportunity for households in 3 big cities in Australia. Mohammed (2011) escalated the main aspect in understanding the design philosophy for safe and economical design of a water tank. For this purpose, a computer program has been developed to check numerical models. It was observed that increase in tank capacity leads to increase in minimum total cost in rectangular and decrease in circular. According to Al-Shayea and Zeedan (2012) the foundation problem usually divided in to three basic components: superstructure, mat and subgrade "soil" just prior to the availability of digital computers. For this purpose, the authors used STAAD Pro software to overcome the shortcoming of the separate modelling of each aforementioned parts. The results were summarized in the form of design charts to show the relationship between thicknesses of mat foundation with various design parameters. Chen, Sun, Yu, and Zeng (2009) proposed a new modelling method of FEA was established for large liquid-storage tank which were based on settlement difference. In the modelling, the settlement difference between RC ring wall and elastic foundation had been utilized as boundary condition instead of bedding value and elastic modulus. The results showed that the results of the proposed method are close to measured values.

It was stated from the review of literature that a computer software can be used to analysis and design a RC structure including a water storage tank. It was found that there is a gap in the information regarding a comparative study between hand calculations and possible available simulation software's for real full scale water tanks. For this reason, the main aim of this study is to conduct a comparison between the analysis and design hand calculations results of a full scale real case drinking water tank of parameters with those calculated using FEM programmers ETABS , Sap2000 and SAFE . In this comparison, moments, shear forces and steel reinforcements values are compared for different elements of the full scale tank. The study involves a parametric study considering water level (storage condition) and soil bearing capacity as variables. It is believed that such comparative study and the proposed parametric study will provide a promising results. It might be a great choice to avoid any wasting of time of hand calculations and will provide a cost effective scheme from engineering prospective.

\section{METHODOLOGY, MANUAL ANALYSIS AND DESIGN}

This paper describes first a hand calculations verses FEM results of RC real full scale rectangular drinking water tank resting on the ground as a case study in Duhok city. Two identical resting on ground water tanks of a 9000 cubic meter capacity and having $50 \mathrm{~mm}$ joint in between have been undertaken as a case study. The maximum height for storing is $8 \mathrm{~m}$ so a freeboard of one meter has been provided. Each surface tank is supported by a fixed base boundary condition. Frame structure has been supported by 27 columns. External shear walls and mat foundation have $900 \mathrm{~mm}$ thickness while interior shear walls are $750 \mathrm{~mm}$ in

yaman.alkamaki@uod.ac, rondik.adil@uod.ac, gulan@uod.ac, a.alsaad2012@gmail.com 
thickness. The roof slab is ribbed slab with equivalent thickness equal to $100 \mathrm{~mm}$. The soil under the mat foundation was modeled as springs which idealize the soil behavior. The bearing capacity of soil was $120 \mathrm{kN} / \mathrm{m}^{2}$. The wall and foundation of the real water tank are designed according to ACI 318 (2014) and ACI 350 (2007) codes by improvising the effects of the lateral loads of water level on walls, see Figure 1. The walls have edge supported floor system. Moment coefficient method was used for analysis. Two cases of mat foundation are undertaken, empty or full tanks. The maximum negative moment of the case of empty tank is about $(147 \mathrm{kN} . \mathrm{m} / \mathrm{m})$ while the maximum negative moment in case of full tank is (44 $\mathrm{kN} . \mathrm{m} / \mathrm{m}$ ). So the foundation design of empty case has been undertaken. The full real tanks details are given in Table 1 .
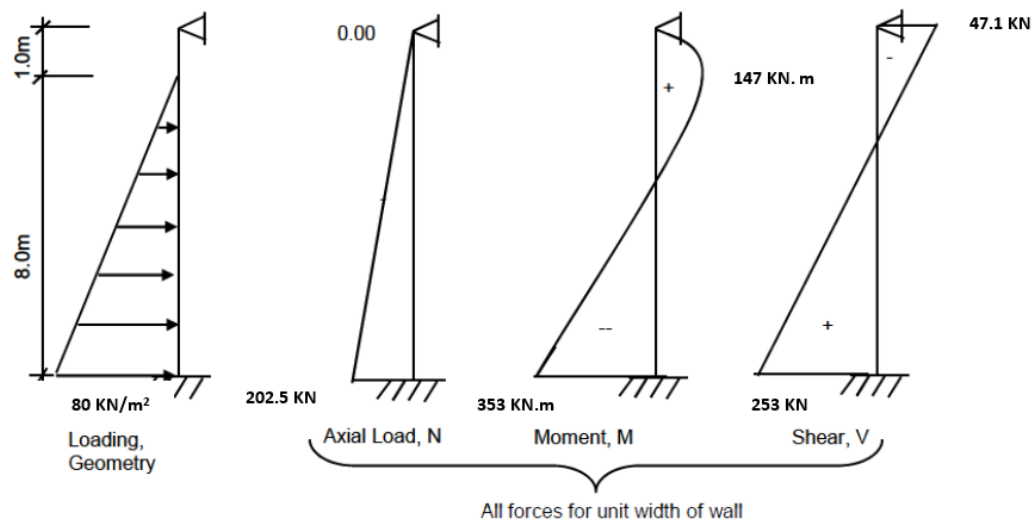

Fig. (1): Tank exterior walls hand calculations.

Table (1): Details of one rectangular ground water tank

\begin{tabular}{lll}
\hline Location & Duhok City & \\
\hline Capacity of tank & 9000 cubic meter & \\
\hline Length & $50 \mathrm{~m}$ & $\Rightarrow$ Overall depth $=310 \mathrm{~mm}$ \\
\hline Width & $20 \mathrm{~m}$ & $\Rightarrow$ Slab thickness $=60 \mathrm{~mm}$ \\
\hline Height & $9 \mathrm{~m}$ & $\Rightarrow$ Stem width at top $=150 \mathrm{~mm}$ \\
\hline Roof Slab & Ribbed Slab according to ACl 318 & \\
& $\Rightarrow$ & $\Rightarrow$ Stem width at bottom $=100 \mathrm{~mm}$ \\
\hline Foundation & $900 \mathrm{~mm}$ & $\Rightarrow$ Rib spacing $=800 \mathrm{~mm}$ \\
thickness & $900 \mathrm{~mm}$ & $\Rightarrow$ For each rib, maximum top area of steel $=226.2 \mathrm{~mm}^{2}$ \\
\hline Side Wall thickness & $(700 \times 300) \mathrm{mm}$ & $\Rightarrow$ For each rib, maximum bottom area of steel $=402.1 \mathrm{~mm}^{2}$ \\
\hline Beam size & $(600 \times 600) \mathrm{mm}, \quad$ total 27 columns & \\
\hline Column size & per tank & \\
\hline Concrete Grade & $\mathrm{C} 25 \mathrm{MPa}$ & $120 \mathrm{kN} / \mathrm{m}^{2}$ \\
\hline Steel grade & $420 \mathrm{MPa}$ &
\end{tabular}

yaman.alkamaki@uod.ac, rondik.adil@uod.ac, gulan@uod.ac, a.alsaad2012@gmail.com ${ }^{2}$ Corresponding author: Water Resources Engineering Department, College of Engineering, University of Duhok, 


\section{FINITE ELEMENT MODELING USING ETABS17, SAP 2000 AND SAFE}

The FEM or FEA is a numerical tool used for solving engineering problems. It comprises the use of mesh generation approaches for dividing a complex problem into small elements. For carrying out the numerical analysis of the two real on ground tanks by means of structural analysis and design simulation, ETABS version 17, SAP 2000 Version 16 and SAFE 17 programs were used. The applied load is taken as triangular water pressure with zero value at the top and a maximum value at the tank base. The dead load of the tank includes the self-weight of the structure and all other superimposed dead loads (all permanent constructions and installations including weight of all side slabs). Analysis and design programmes such as ETABS, SAP 2000 and SAFE often ask for an

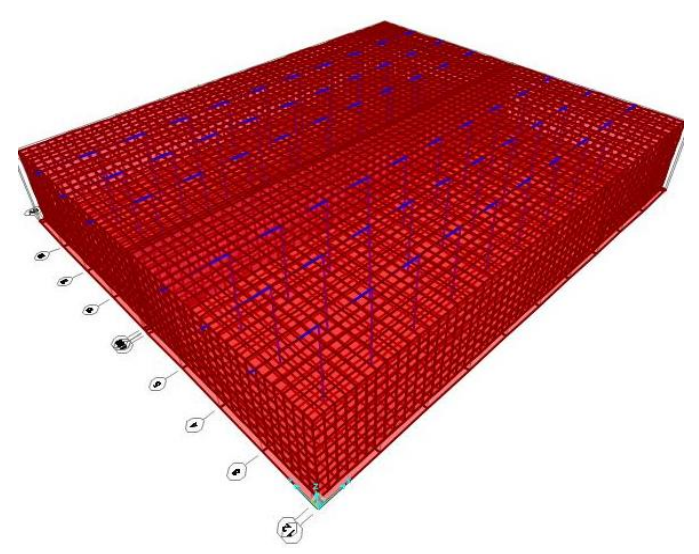

input called "modulus of subgrade reaction (Ks)" which is defined as the ratio of the pressure against the mat to the settlement at a given point, $\mathrm{Ks}=\mathrm{q} / \delta$. The unit of $\mathrm{Ks}$ is $\mathrm{kN} / \mathrm{m}^{2} / \mathrm{m}$. Where: $\mathrm{q}$ is the soil pressure at a given point and $\delta$ is the settlement of the mat at the same point. For members in contact with the liquid (e.g. inner faces or roof slab), $25 \mathrm{~mm}$ is the minimum cover to all reinforcement or it can be diameter of the main bar whichever has the highest value. For faces and parts of the structure which have not have in any contact with the liquid, the cover shall be as for ordinary concrete member. The walls of the tank are designed as a fixed at the base and simply supported from the top. The tanks were analysed based on their weight and the hydrostatic pressure of internal water level. Figures 2 shows the Three-dimension (3D) view of the identical water tanks

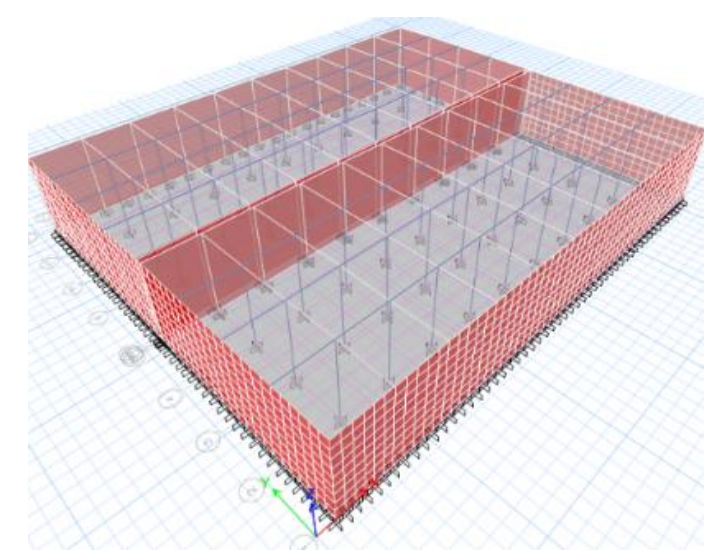

Fig. (2): 3D modelling by SAP 2000 (left) and by ETABS (right).

\subsection{Long and short walls}

Since the short walls as well as long walls are subjected to bending moment and direct tension or pull acting at center of wall, it will be necessary to design the wall section for combined effect of these two factors. The bending moments for both long and short walls simulated by ETABS and SAP 2000 are shown in Figures 3 and 4 respectively. The maximum values are in the direction of water which is reflected between water face to air face nearly about the centre of walls. The Figures show that the outcomes from ETABS and SAP 2000 analysis are in good agreement.

yaman.alkamaki@uod.ac, rondik.adil@uod.ac, gulan@uod.ac, a.alsaad2012@gmail.com 


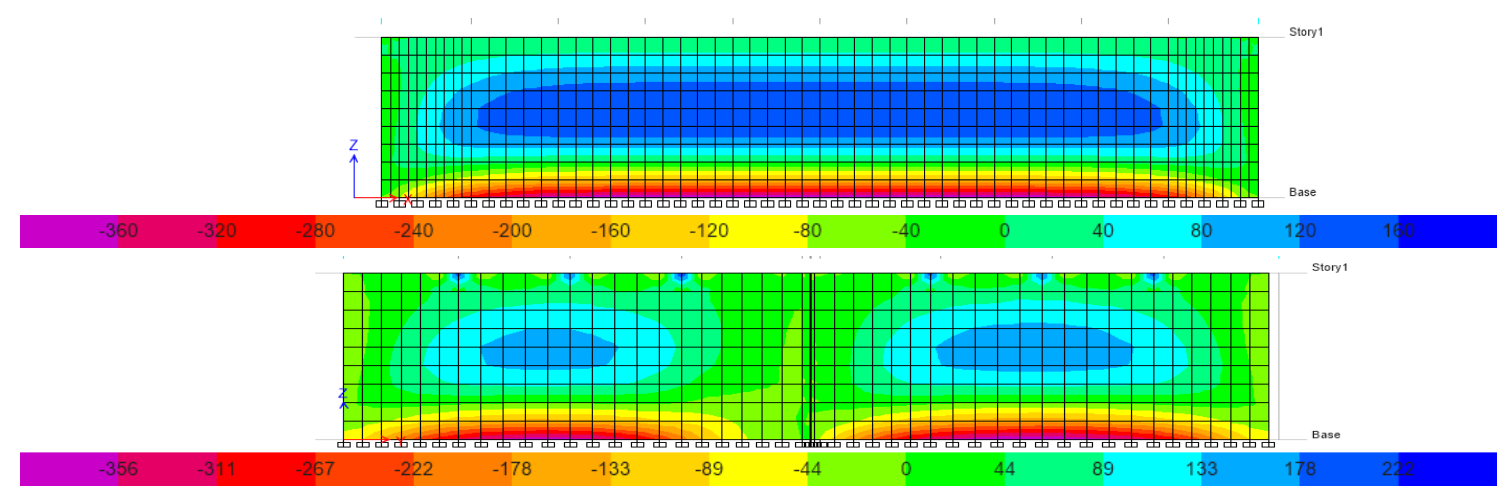

Fig. (3) Flexural moments of long and short walls by ETABS.
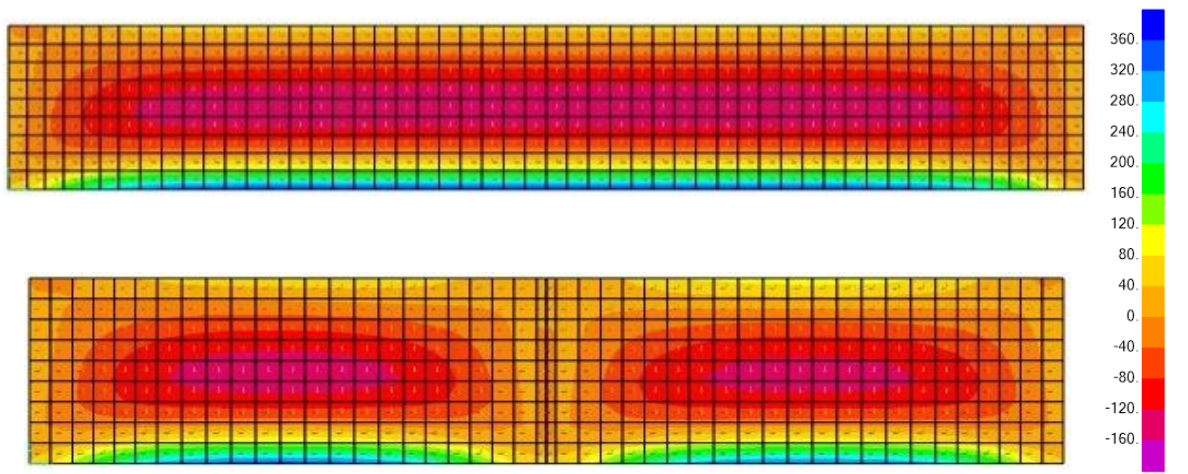

Fig. (4) Flexural moments of long and short walls by SAP 2000.

The value of axial load by ETABS was 216 $\mathrm{kN}$ at bottom and zero at top which is very close to the hand calculation. The tank walls are also subjected to shear force. For such reason it is important to calculate the shear force for the walls. Figure 5 shows the shear force results obtained from ETABS while Figure 6 reflects such values acquired by SAP2000. Again, the FEM predictions are in good agreement for both software data sets.

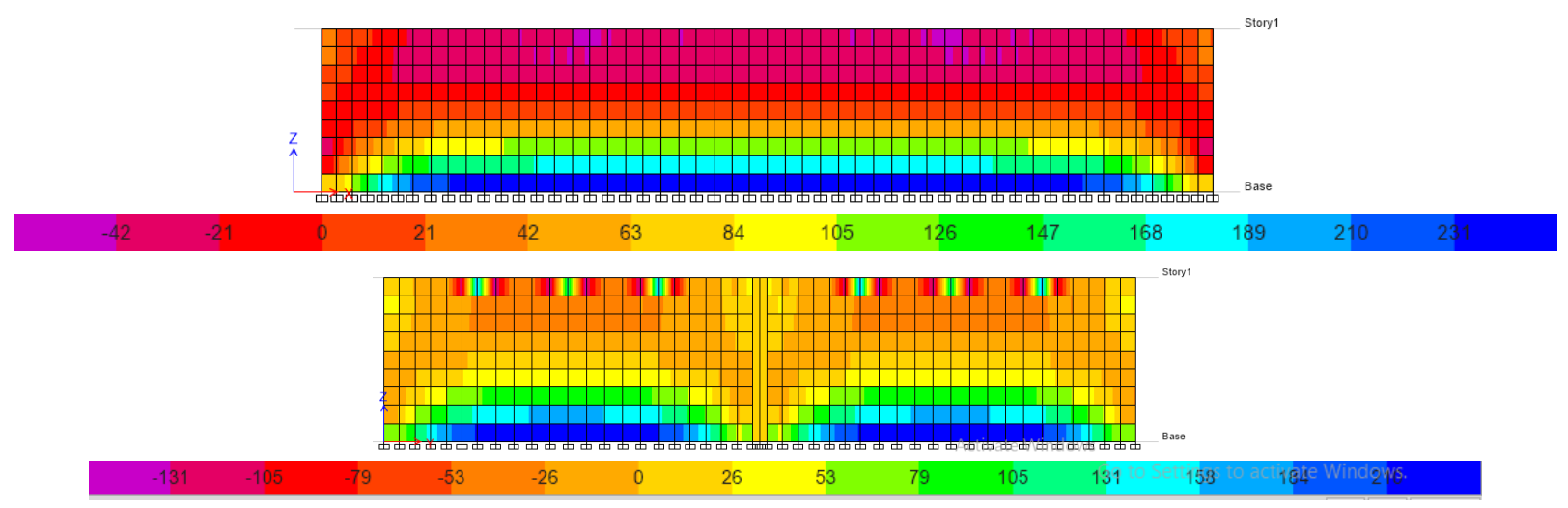

Fig. (5): Shear force in long and short walls by ETABS

yaman.alkamaki@uod.ac, rondik.adil@uod.ac, gulan@uod.ac, a.alsaad2012@gmail.com ${ }^{2}$ Corresponding author: Water Resources Engineering Department, College of Engineering, University of Duhok, Kurdistan Region, Iraq 


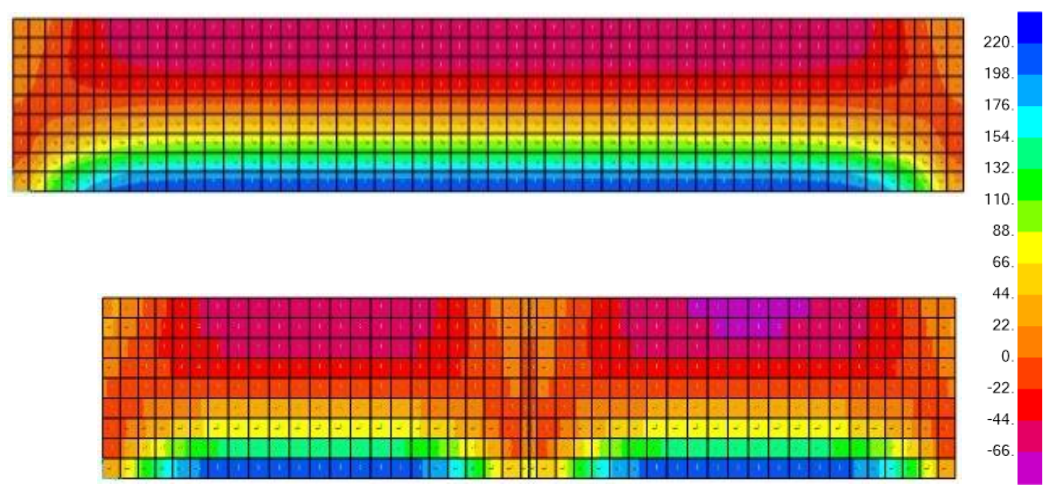

Fig. (6): Shear force in long and short walls by SAP 2000.

\subsection{Ribbed Slab}

Ribbed slabs are used for structures that support fairly small live loads and the spans comparatively long. In this comparative study, the roof slab is designed as a ribbed slab with columns spaced at $5 \mathrm{~m}$ apart. Reinforcement for the joists usually consists of the two bars in the positive bending region, with one bar discontinued where no longer needed or bent up to provide a zone of the negative steel requirement over the supporting girders. Straight top bars are added over the support which provided for the negative moment, this has been done as well by a study established by Darwin, Dolan, and Nilson (2016). Figure 7 shows the slab details based on hand calculations outcomes. To determine the steel area using FE software, a bending moment is required. Figure 8 illustrates the moment values calculated using SAFE.
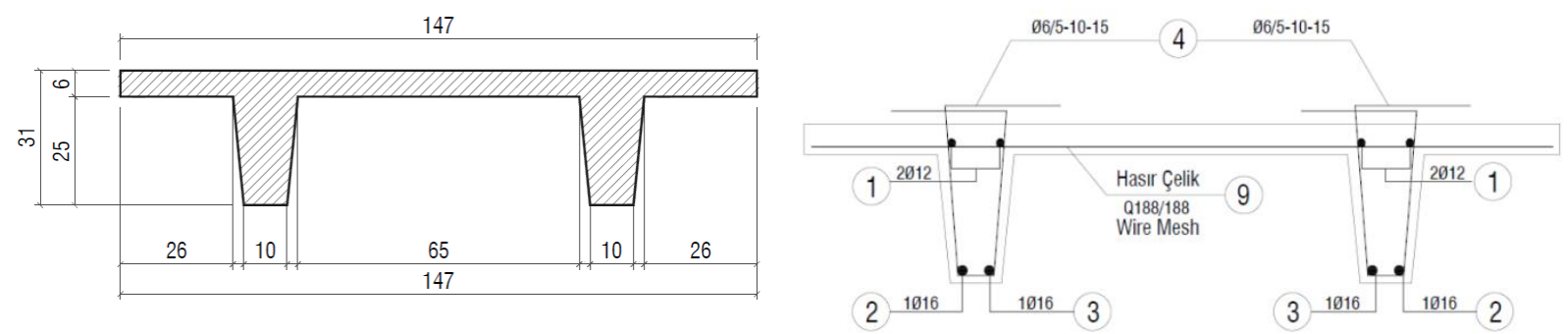

Fig. (7): Ribbed slab view and reinforcement details from hand calculations

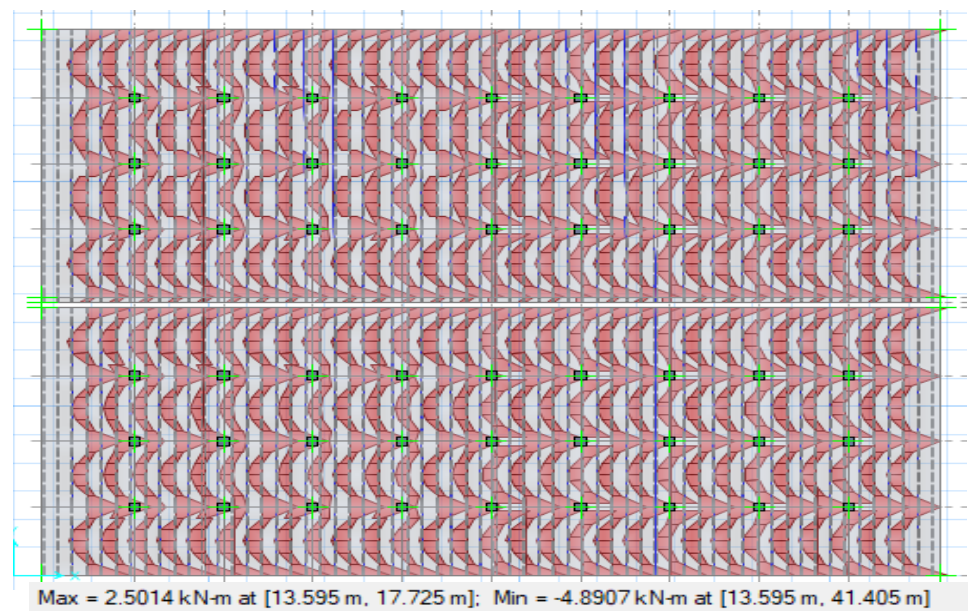

Fig. (8):.Moments in ribbed slab by SAFE.

yaman.alkamaki@uod.ac, rondik.adil@uod.ac, gulan@uod.ac, a.alsaad2012@gmail.com ${ }^{2}$ Corresponding author: Water Resources Engineering Department, College of Engineering, University of Duhok,

Kurdistan Region, Iraq 


\subsection{Mat foundation}

In general foundation is the lower part of the structure which is in direct contact with the soil and loads to the ground. Mat foundation is thick $\mathrm{RC}$ slab covering the entire area underneath the structure. It provides an economical solution under certain difficult site conditions. Such kind of foundations is one of the categories that mostly considered in water storage tanks. Figure 9 shows the base slab moment in $\mathrm{kN} . \mathrm{m} / \mathrm{m}$ computed for empty tank case using SAFE. A volume of 9000 cubic meter was adopted form hand calculations using a spring constant of soil for unit width $12000 \mathrm{kN} / \mathrm{m}(1200 \mathrm{t} / \mathrm{m})$.

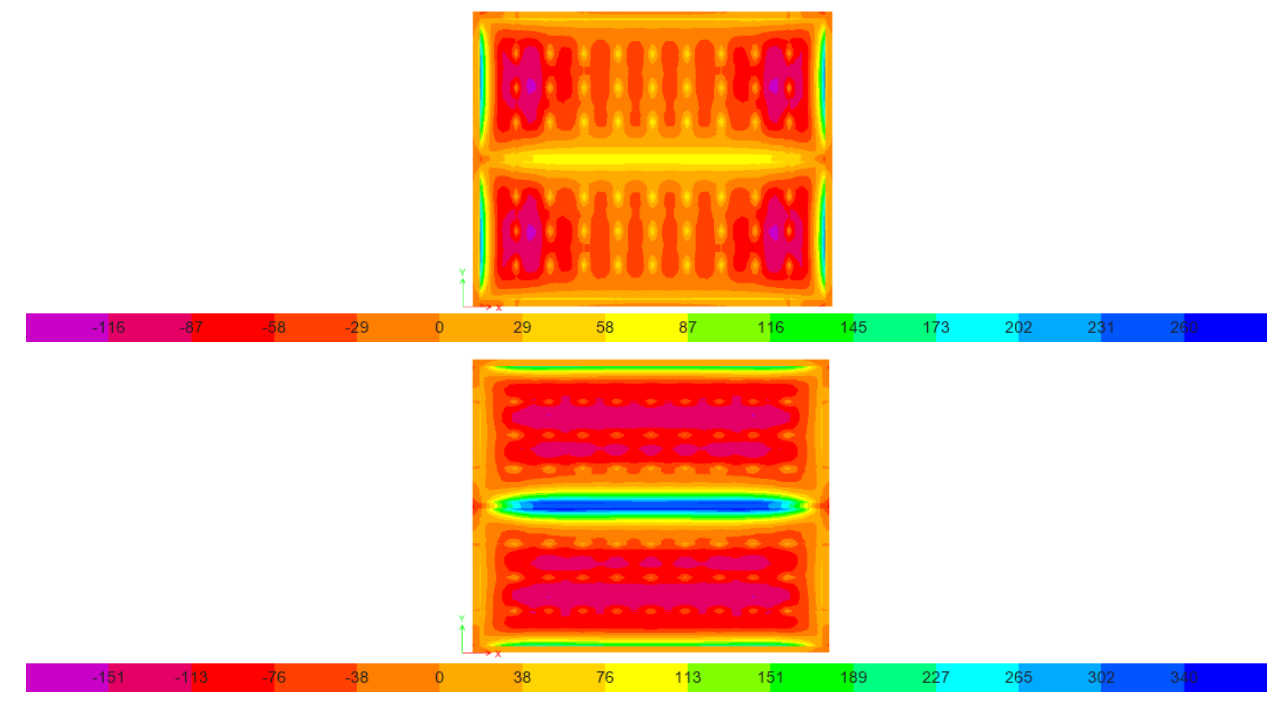

Fig. (9): Mat moment for empty case by ETABS in x-y direction.

\section{RESULTS AND DISCUSSION}

Referring to section 3.1, the maximum moment occurs at bottom of wall in the direction of water face and in the middle of wall the moment is reflected to air face. Figure 10 shows that there is a good agreement between ETABS, SAP2000 and hand calculation. This points a possibility to depend on programs like ETABS and SAP200 for the analysis and design of water tank shear walls. Furthermore, the value of shear force calculated by ETABS and SAP 2000 is nearly equal, see Figure 11. In addition to that Figure 11 shows a comparison among the two software used along with the hand calculation and the Figure illustrates that there is a good agreement.
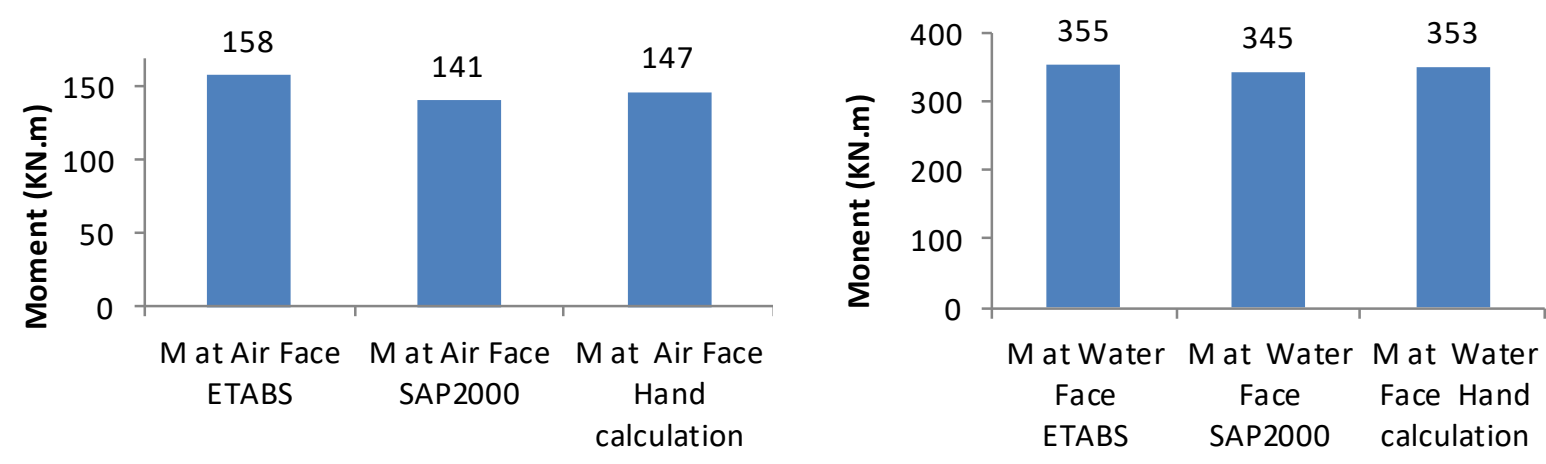

Fig. (10): Comparison of long walls moments (air and water faces).

yaman.alkamaki@uod.ac, rondik.adil@uod.ac, gulan@uod.ac, a.alsaad2012@gmail.com ${ }^{2}$ Corresponding author: Water Resources Engineering Department, College of Engineering, University of Duhok, Kurdistan Region, Iraq 

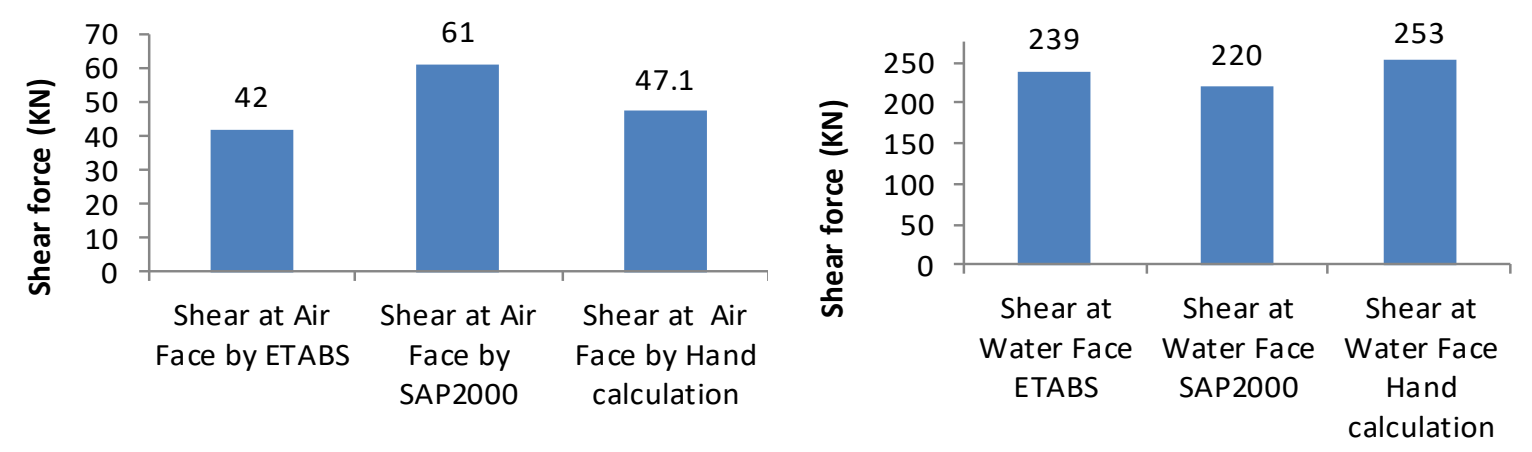

Fig. (11): Comparison of long walls shear forces (air and water faces).

The shear walls reinforcement area in $\mathrm{mm}^{2}$ (design of the walls) can be calculated directly from ETABS program, main reinforcement is vertical whereas for the shear reinforcement is horizontal, see Figure 12. On the other hand, SAP2000 software is unable to calculate such reinforcement area directly but it can be calculated by implementing moment equation. ETABS provides a $2250 \quad \mathrm{~mm}^{2} / \mathrm{m}$ shear reinforcing (horizontal steel area), see Figure 12. Vertical area of steel for the total long wall length $(50 \mathrm{~m})$ is $110926 \mathrm{~mm}^{2}$ while for short wall $(20 \mathrm{~m})$ is $45875 \mathrm{~mm}^{2}$, see Figure 12. Such amount of reinforcement can be converted to spacing’s $\varnothing 20 \mathrm{~mm} @ 140 \mathrm{~mm}$ c/c for both vertical and horizontal bars using the appropriate formula. While hand calculations provided $\varnothing 20$ mm@100 mm c/c during the execution.

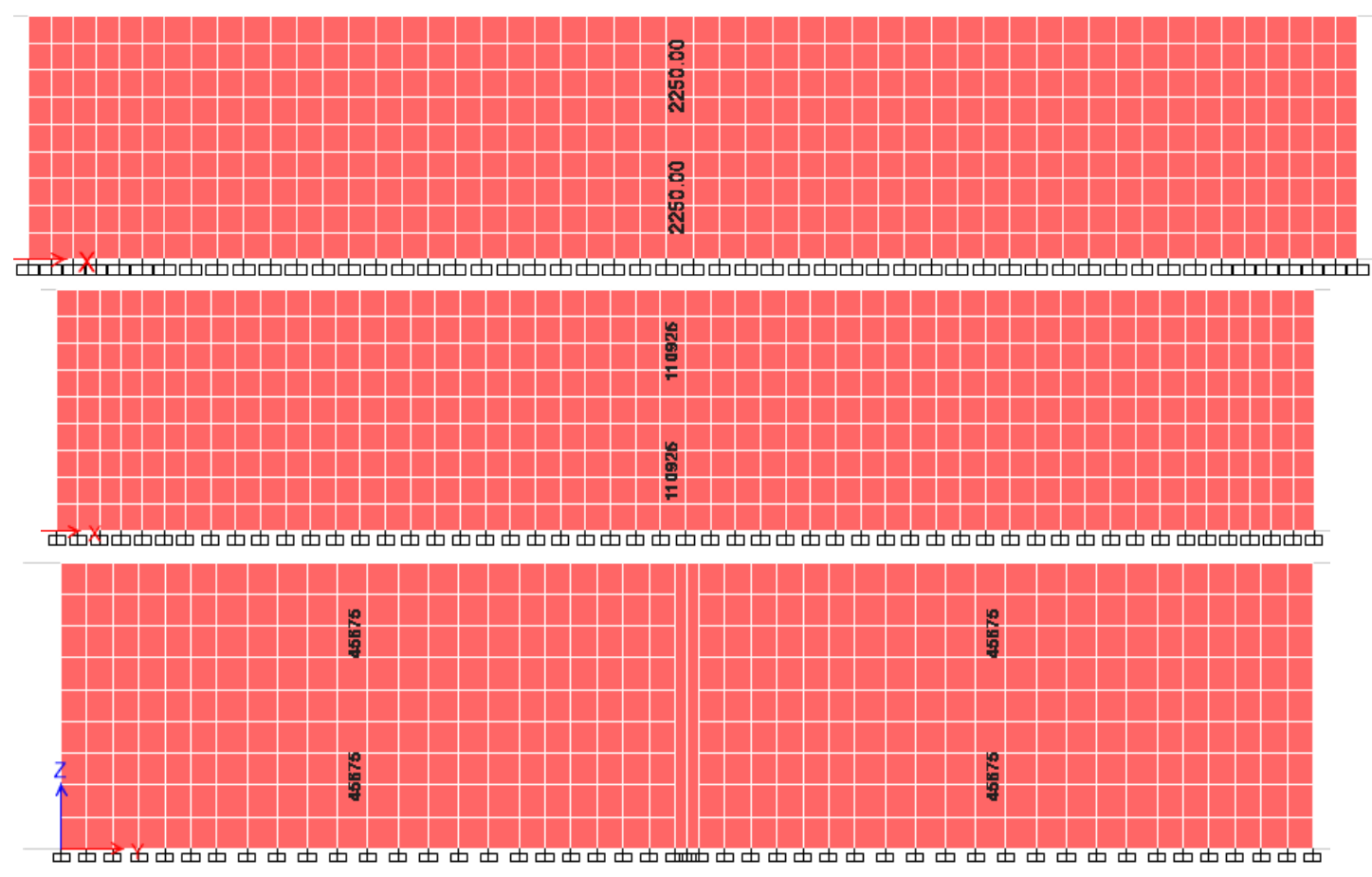

Fig. (12): Long and short walls main reinforcement by ETABS

yaman.alkamaki@uod.ac, rondik.adil@uod.ac, gulan@uod.ac, a.alsaad2012@gmail.com ${ }^{2}$ Corresponding author: Water Resources Engineering Department, College of Engineering, University of Duhok, Kurdistan Region, Iraq 
Referring to section 3.2, the hand calculation calculations have used $2 \varnothing 12 \mathrm{~mm}$ at top and $2 \varnothing$ $16 \mathrm{~mm}$ at bottom, as shown in Figure 7 displayed previously. For each rib, the maximum steel reinforcement required by SAFE was $1 \varnothing$ $12 \mathrm{~mm}$ at top and $1 \varnothing 16 \mathrm{~mm}$ at the bottom of the slab. This is clearly demonstrating that the hand calculations are not economic.

Discussing section 3.3, ETABS and SAFE can design the mat and calculate area of steel directly according to the subjected moment values. As in ACI code, ETABS draw strips (column strip and middle strip) and calculate

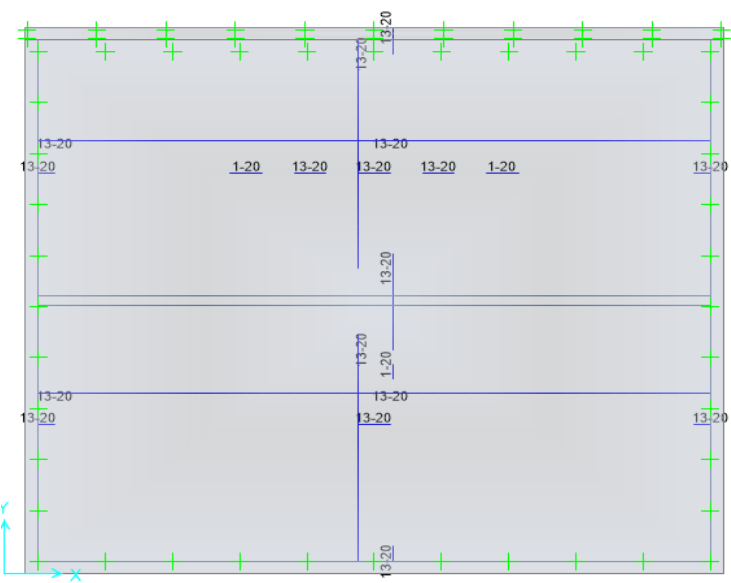

Fig. (13): Mat steel area for empty case SAFE (left) and ETABS (right) for both directions (column strip width $2.5 \mathrm{~m}$ )

\section{PARAMETRIC STUDY}

\subsection{Influence of water level}

The deformation of water tank walls is changeable according to level of water inside, see Figure 14 which shows 3 different cases (empty, half full and full). In case of full water level, the deformation of walls is in two opposite direction air face and water face while the deformation of walls in the case of half full is differ. In the case of empty water level, the defamation approach zero in all directions. Figure 15 shows the comparison between the three cases, the moment at water face is higher

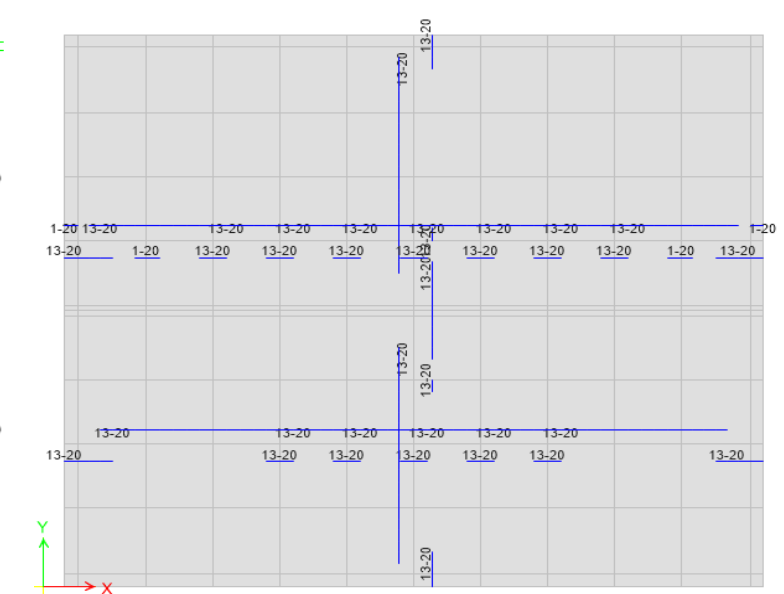

steel required per each strip. Figure 13 shows a steel required for one strip with length equal to $2.5 \mathrm{~m}$ which is total length of panel equal to $5 \mathrm{~m}$ divided by two as in ACI code. The Figures show that the area of steel from SAFE is nearly equal the area of steel get from ETABS. Spacing of bars for mat determined by ETABS and SAFE are Ø20 mm @ $190 \mathrm{~mm} \mathrm{c} / \mathrm{c}$. While for hand calculation foundation provided Ø20 mm @ $100 \mathrm{~mm} \mathrm{c} / \mathrm{c}$ during implementation phase. It is concluded that software is more economical than hand calculation. A gain it is very obvious that the hand calculations are very conservatives. 

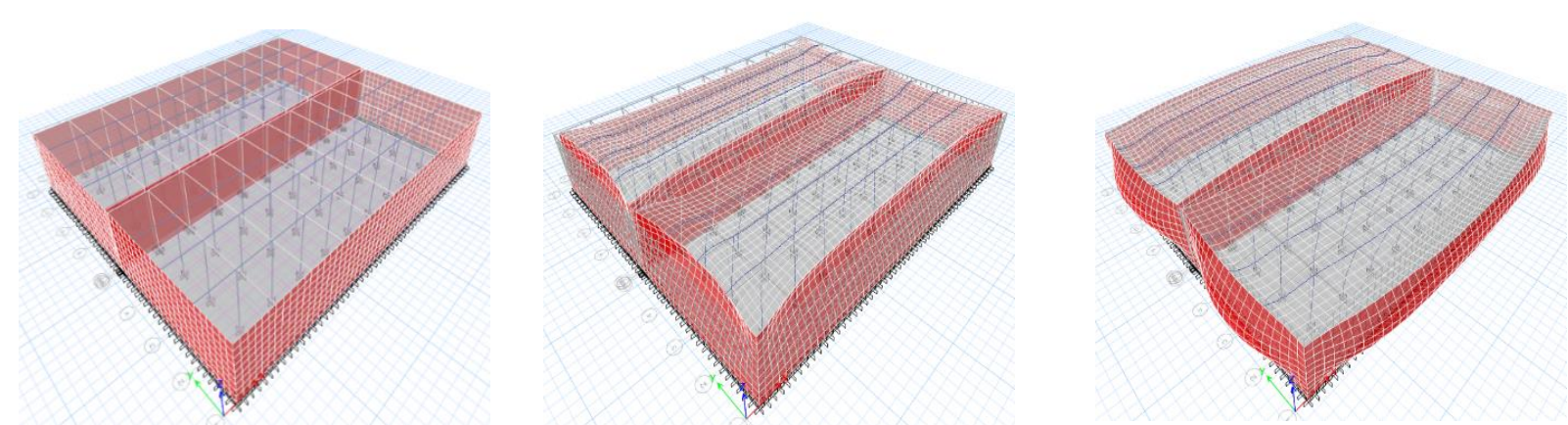

Fig. (14): Deformation of Walls by Etabs17, empty (left), half full (middle) and full (right).

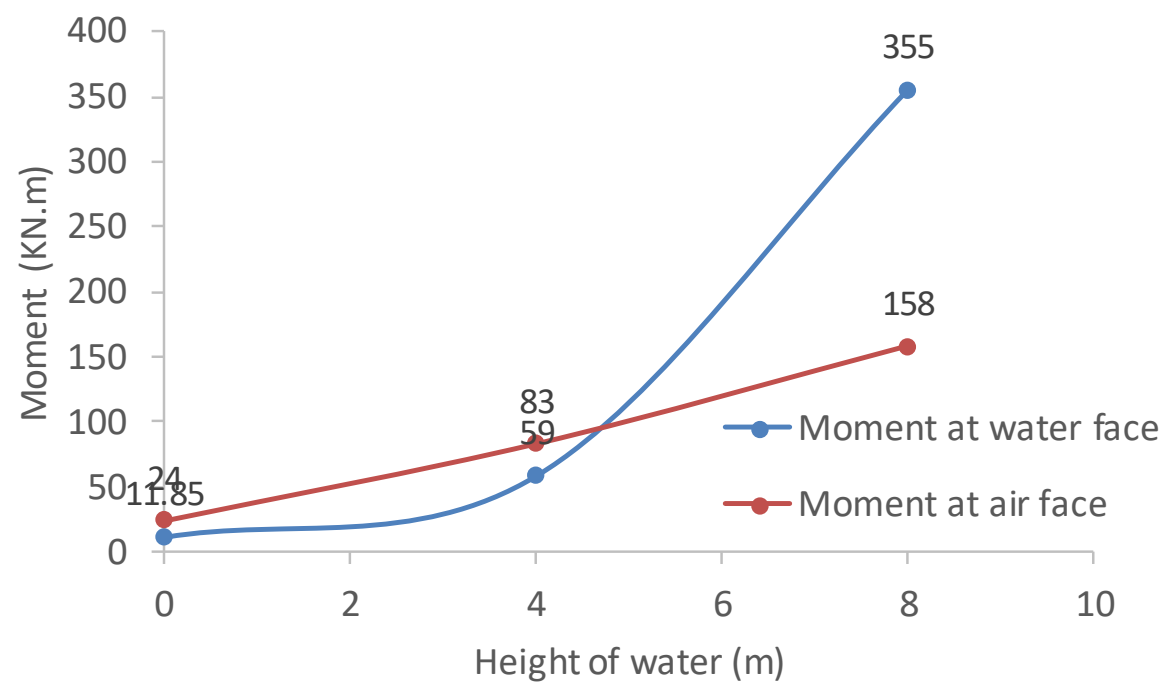

Fig. (15): Comparison of moments of water level cases for long walls (water and air faces) by ETABS.

\subsection{Influence of bearing capacity in mat foundation}

Relation between maximum moment and soil bearing capacity for 3 cases (empty, half full and full) for the mat is shown in Figure 16. A bearing capacity of soil under the mat has been changed 3 times 60,120 and $180 \mathrm{kN} / \mathrm{m}^{2}$. As the bearing capacity of soil increases, the design moment decrease. Thus for soft soil, the bending moment is high while in hard soil, the bending moment is less. In this parametric study, when soil bearing capacity changes from $120 \mathrm{kN} / \mathrm{m}^{2}$ to $60 \mathrm{kN} / \mathrm{m}^{2}$, the moment at empty state still more than the moment at half full or full situations. When bearing capacity value changes from $120 \mathrm{kN} / \mathrm{m}^{2}$ to $180 \mathrm{kN} / \mathrm{m}^{2}$, still the moment for empty circumstance is the highest. Thus, for design purposes the empty water tank case should be considered for design purposes.

yaman.alkamaki@uod.ac, rondik.adil@uod.ac, gulan@uod.ac, a.alsaad2012@gmail.com ${ }^{2}$ Corresponding author: Water Resources Engineering Department, College of Engineering, University of Duhok, Kurdistan Region, Iraq 


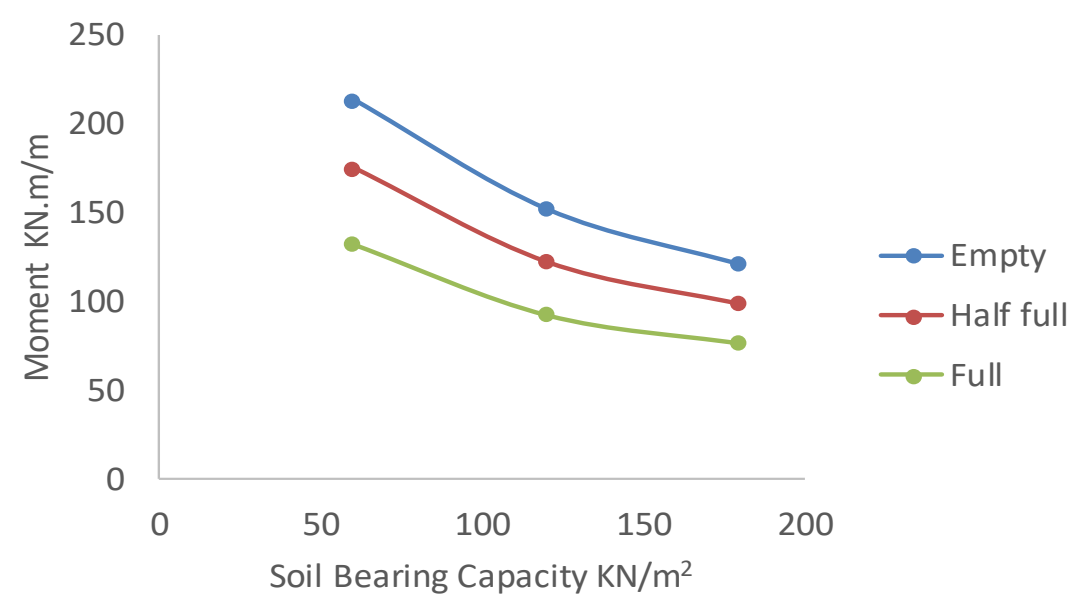

Fig. (16): Foundation moment changes according to soil bearing capacity by ETABS.

It is known that every foundation settles by some amount due to load caring capacity of the entire structure. As a result, a displacement occurs for the soil underneath which results expect movements. For such reason, it is very essential that a check to be carried out otherwise the entire structure may fail due to differential settlement of the foundation. For serviceability, settlements and soil pressure were considered in this parametric study. Although, the settlement is influenced by the water level in tank but it also affected by the soil classification. Figure 17 shows the relationship between the settlement and bearing capacity. The mat exhibited uniform settlement for all conditions but the settlement decreased as the foundation bearing capacity increased. It is also noticed that the magnitude of settlement is high for full case and low for empty condition. The settlement comparison values of the foundation under the design load is determined by ETABS programmer is shown in Figure 17. The Figure illustrates that the maximum settlement is changed according to the level of water in the tank. In case of empty tank, half fall and full, the maximum settlement values are $18.3 \mathrm{~mm}, 20.9 \mathrm{~mm}$ and $23.6 \mathrm{~mm}$ respectively calculated from ETABS and the settlement values increased as water level increased.

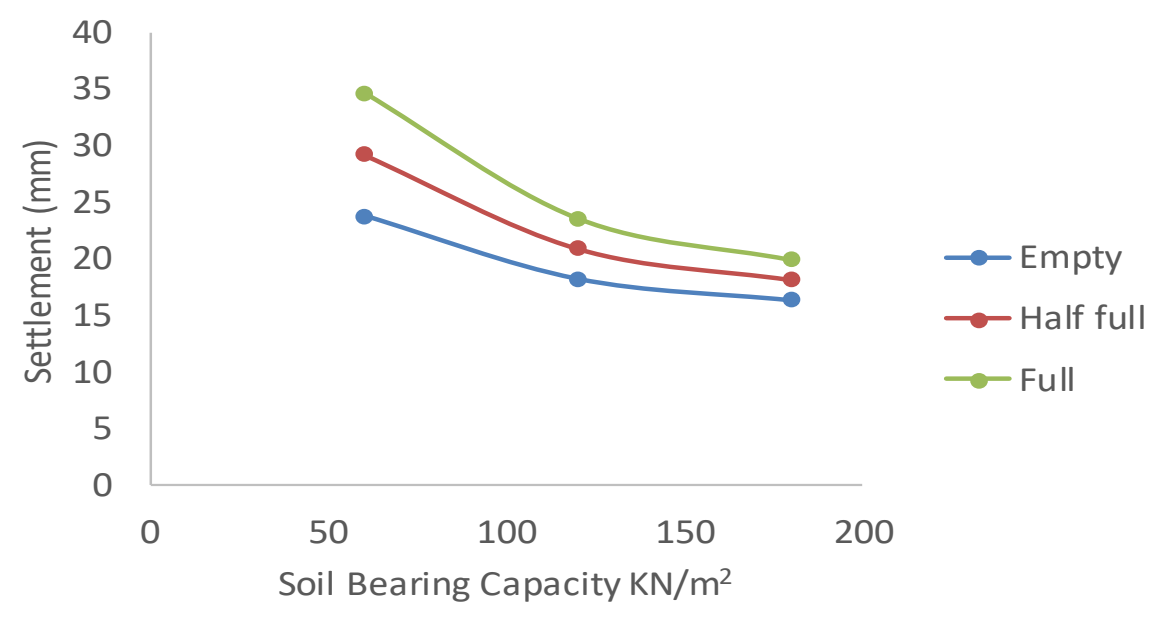

Fig. (17): Mat settlement according to bearing capacity

yaman.alkamaki@uod.ac, rondik.adil@uod.ac, gulan@uod.ac, a.alsaad2012@gmail.com ${ }_{2}^{2}$ Corresponding author: Water Resources Engineering Department, College of Engineering, University of Duhok, Kurdistan Region, Iraq 


\section{CONCLUSION}

In this study, a comparative and parametric study has been undertaken to address a full real drinking ground water tank a case study in Duhok city. The hand calculations analysis and design were conducted first followed by FEM analysis and design using ETABS, SAP2000 and SAFE software. Tank walls, slab and mat foundation were simulated then compared to hand calculations. Bending moments, shear forces and steel reinforcement values have been covered and compared in this study. Furthermore, it is difficult to change any factor in hand calculations as it will require redesign and time consuming. A parametric study has been undertaken considering those parameters not covered in the hand calculations. Changes in the water level in the tank and the soil bearing capacity effect on settlements were examined. Results show that there is a good agreement obtained using ETABS and SAP 2000 compared to hand calculations. It was concluded the mat can be designed by ETABS as well and there is no much difference compared to SAFE. It was obvious that the tank must be empty when the mat design is required as in this case the bending moment becomes maximum. It was noted that the settlement increases while water level increase and soil bearing capacity decrease. The main conclusion highlighted in this study is the fact that the hand calculation steel amounts were very conservatives. About half of area of steel was required during the execution as stated when using FEM programs.

\section{REFERENCES}

AbdulMuttalib I. Said and Ammar A. AbdulMajeed. (2011). Seismic analysis of liquid storage tanks. Journal of Engineering, 17(3), 610-619.

ACI 318. (2014). Building Code Requirements for Structural Concrete (ACI 318-11). Paper presented at the American Concrete Institute.

ACI 350. (2007). Code Requirements for Environmental Engineering Concrete Structures and Commentary (ACI 350-06): An ACI Standard.

Ajagbe, W., Ilugbo, E., Labiran, J., \& Ganiyu, A. (2015). Analysis and Design of a Fully Submerged Undergorund Water Tank Using the Principle of Beam on Elastic Foundation. Paper presented at the UITECH Conference.

Al-Shayea, N., \& Zeedan, H. (2012). A New Approach for Estimating Thickness of Mat Foundations Under Certain Conditions. Arabian Journal for Science and Engineering, $37(2)$, 277-290. doi:10.1007/s13369-012-0178-5

Bekele, S. S. (2019). Investigation on Foundation Design Practice of Water Storage Tank in Case of Gonder and Dembi-Dollo Sites. (MSc), Addis Ababa Science and Technology University, Addis Ababa, Ethiopia.

Bureau of Indian Standards. (1967). I.S.: 3370 : Code of Practice Concrete structures for the storage of liquids. In Part 1. New Delhi.

Bureau of Indian Standards Part 21893 BIS, I. (2002). Indian standard criteria for earthquake resistant design of structures. Bureau of Indian Standards, New Delhi.

Chau, K. W., \& Lee, S. T. (1991). Computer-aided design package RCTANK for the analysis and design of reinforced concrete tanks. Computers \& Structures, 41(4), 789-799. doi:https://doi.org/10.1016/0045-7949(91)901 88-R

Chen, Z., Sun, B., Yu, C., \& Zeng, M. (2009). Finite-element analysis of liquid-storage tank foundations using settlement difference as boundary condition. Proceedings of the Institution of Mechanical Engineers, Part E:

yaman.alkamaki@uod.ac, rondik.adil@uod.ac, gulan@uod.ac, a.alsaad2012@gmail.com

${ }^{2}$ Corresponding author: Water Resources Engineering Department, College of Engineering, University of Duhok,

Kurdistan Region, Iraq 
Journal of Process Mechanical Engineering, 223(4), 225-231.

Darwin, D., Dolan, C. W., \& Nilson, A. H. (2016).

Design of concrete structures: McGraw-Hill Education.

Elansary, A. (2016). Behaviour of Reinforced Concrete and Composite

Conical Tanks Under Hydrostatic and Seismic

Loadings. (PhD), The University of Western Ontario, Ontario, Canada.

ETABS. Three Dimensional Analysis and Design of Building Systems: Computers and Structures, Inc., version 17.

Gate'a, M. A., \& Atalla, A. (2015). Dynamic analysis of elevated tanks having various supporting frame configurations. Journal of Univesity of Thi-Qar, 10(2), 1-13.

Ghandhi, M., \& Rajan, A. (2014). Necessity of dynamic analysis of elevated water storage structure using different bracing in staging. international Journal of research in advent Technology, 2(2).

Gulin, M., Uzelac, I., Dolejš, J., \& Boko, I. (2017). Design of Liquid-Storage Tank: Results of Software Modeling Vs Calculations According to Eurocode. E-GFOS, 8(15), 85-97.

Hilo, S. J., \& Badaruzzaman, W. W. (2011). Cost Optimisation of Water Tanks Designed According to The ACI and Euro Codes. Iqbal, M. I., Chowdhury, M. R. A., Sarker, D., \& Anwar, A. T. (2015). Finite Element Analysis of Fully Buried Underground Water Tank by SAP2000.

Kukreti, A. R., \& Siddiqi, Z. A. (1997). Analysis of fluid storage tanks including foundation-superstructure interaction using differential quadrature method. Applied Mathematical Modelling, 21(4), 193-205. doi:https://doi.org/10.1016/S0307-904X(97)00 $\underline{007-3}$

Magnucki, K., \& Stasiewicz, P. (2003). Critical sizes of ground and underground horizontal cylindrical tanks. Thin-Walled Structures, 41(4),

317-327.

doi:https://doi.org/10.1016/S0263-8231(02)00 $\underline{097-6}$

Mohammed, H. J. (2011). Economical design of water concrete tanks. European journal of scientific research, 49.

Naik, S. C., \& Bhandiwad, M. (2016). Seismic Analysis and Optimization of a Rectangular Elevated Water Tank. Bonfring International Journal of Man Machine Interface, 4(Special Issue Special Issue on Computer Aided Analysis and Design of Structures| Editors: Dr. DK Kulkarni, Dr. RJ Fernandes, Dr. SB Kulkarni), 83-89.

Nallanathel, M. M., Ramesh, M. B., \& Jagadeesh, L. (2018). Effective Utilization of Staad Pro in The Design and Analysis of Water Tank. International Journal of Pure and Applied Mathematics, 119(17), 3081-3088.

Patel, B., \& Shah, D. (2010). Formulation of Response Reduction Factor for RC Framed Staging of Elevated Water Tank Using Static Pushover Analysis. Paper presented at the Proceeding of the World Congress on Engineering.

Qureshi, L. A., Amin, K., Janjua, N., \& Tahir, F. (2013). Comparison of 2D \& 3D Finite Element Analysis of Underground Water Tanks Based on Soil-Structure Interaction using GTS.

SAFE. Design of slabs, beams and foundationsreinforced and post-tensioned concrete Computers and Structures, Inc., version 16.

Sap2000. Integrated solution for structural analysis

yaman.alkamaki@uod.ac, rondik.adil@uod.ac, gulan@uod.ac, a.alsaad2012@gmail.com ${ }^{2}$ Corresponding author: Water Resources Engineering Department, College of Engineering, University of Duhok, Kurdistan Region, Iraq 
and design: Computers and Structures, Inc., version 20 .

SCIA Engineer (2008). Software System for Analysis, Design and Drawings of Steel, Concrete, Timber, Aluminium and Plastic Structures. In: Herk-de-Stad: SCIA Group nv.

Sharma, D. H., Singh, V., \& Sharma, S. (2008). Some Aspects of Computer Aided Design of Underground Water Tanks. Paper presented at the 2nd IASME/WSEAS International Conference on GEOLOGY and SEISMOLOGY (GES'08), Cambridge, UK.

STAAD Pro. United States of America: Bentley Communities.

Tam, V. W. Y., Tam, L., \& Zeng, S. X. (2010). Cost effectiveness and tradeoff on the use of rainwater tank: An empirical study in Australian residential decision-making. Resources, Conservation and Recycling, 54(3), 178-186.

doi:https://doi.org/10.1016/j.resconrec.2009.07 $\underline{.014}$

Threlfall, A. J. (1978). Design charts for water retaining structures to BS5337: Cement and Concrete Association.

Titiksh, A. (2019). Parametric study on cylindrical water tanks by varying their aspect ratios. Asian Journal of Civil Engineering, 20(2), 187-196.

Yazdanian, M., Razavi, S., \& Mashal, M. (2016). Seismic analysis of rectangular concrete tanks by considering fluid and tank interaction. Journal of Solid Mechanics, 8(2), 435-445.

Yukio, N. (2010). Design Recommendation for Storage Tanks And Their Supports with Emphasis on Seismic Design. Architectural Institute of Japan, Academia. edu, 176.

Zhao, D., Hu, Z., Chen, G., Lim, S., \& Wang, S. (2018). Nonlinear sloshing in rectangular tanks under forced excitation. International Journal of Naval Architecture and Ocean Engineering, $\quad 10(5)$, 545-565. doi:https://doi.org/10.1016/j.ijnaoe.2017.10.00 $\underline{5}$

yaman.alkamaki@uod.ac, rondik.adil@uod.ac, gulan@uod.ac, a.alsaad2012@gmail.com ${ }^{2}$ Corresponding author: Water Resources Engineering Department, College of Engineering, University of Duhok, 